Analysis of Ores, Eoc.-Mr. James M. Camp's method for rapid analysis of blast furnace cinders apparently gives results useful to the blast furnace manager, but the determination of manganese, from Mr. Camp's own showing, cannot be neglected.

The writer has used the colorimetric method both for iron and manganese, especially iron; it is most important to make frequent iron determinations, for obviously iron in the slag is equivalent to loss of metal in the pig-bed. The colour method is rapid, good for iron in slag, and more accurate than the weight process.

Determination of Silica in Ores.--One notes that potassium sulphate or hydrofluoric acid are sparingly used, American chemists relying chiefly on the sodium carbonate method. In this country preference is given to the use of the former ; chemical results are considered more accurate, with economy of time.

Determination of Iron.- The bichromate method leaves nothing to be desired as regards slags, ores or minerals in general, but is not very suitable for the accurate determination in iron or steel. Most chemists are content in iron or steel analysis to give the iron by difference, but if a method could be devised whereby the absolutely pure iron could without question be determined within oor per cent., such a factor would in the present state of our knowledge be invaluable. Those who have studied the recent developments of the chemistry of iron will understand this.

On the whole, American practice seems inferior to the English; some of the methods quoted are practically obsolete in this country. This applies more especially to manganese determinations-only two chemists when using the gravimetric method for manganese take note of the previous necessary removal of barium when ores are being analysed, to say nothing of other possible impurities.

Very many of the processes given seem devised merely for speedy work, regardless of accuracy; on the other hand, some needless complications have been introduced with consequent loss of valuable time.

\section{JOHN PARRY.}

\section{OUR BOOK SHELF.}

Electro-physiology. By W. Biedermann. Translated by Frances A. Welby. Vol, ii. Pp. vii + 500. (London: Macmillan and Co., Ltd., I898.)

MISS WELBY has now completed her translation of this work. The second volume is equal to the first in scientific interest and importance, and the technical difficulties of rendering it into English have been overcome with even greater success.

Prof. Biedermann deals with the main subject of the volume, that of the "electro-physiology" of nerve, much more from a physiological than from an electrical point of view. In every branch of it he is able to give us the results of his own work, or of those of the distinguished colleague with whom he was for so many fruitful years associated at Prague; so that the student who desires to appreciate the experimental basis of Hering's doctrine cannot have a better guide than is here provided for him. It must not, however, be supposed that the work is mainly theoretical ; on the contrary, on the subjects of which it treats, it is the best "reference-book" that the physiological worker has at present at his disposal.

In addition to the chapters on nerve, the volume NO. I 494, VOL. 58] contains a very carefully written chapter on the electrical endowments of the plant-cell, another on electric fishes, and a third on the electrical response of the retina to the stimulus of light. In discussing the first two of these special subjects, Biedermann derives his data chiefly from English sources. In the elaborate and copiously illustrated chapter on electric fishes, the reader will find a complete account of Prof. Ewart's investigations of the development and structure of the electrical organ in the rays; and of Prof. Gotch's researches on Torpedo. In like manner the chapter on the electromotive properties of excitable tissues of plants is mainly based on English researches on Dionaa, of which it contains a very full résumé. It is a satisfaction to the writer of this notice that the main results of his own investigations have been accepted by his German colleague, and particularly to observe how fully he has appreciated the evidence they afford of the essential identity of the elementary pro. cesses of plant and animal life.

J. B. S.

Open-air Studies in Botany: Sketches of British Wildflowers in their Homes. By R. Lloyd Praeger, B.A., B.E., M.R.I.A. Illustrated. (London: Charles Griffin and Co., Ltd., I897.)

THESE open-air studies should appeal to people who live in the country, and who care about the wild plants around them. A glance through the pages recalls many a country ramble, and a good point about the treatment in the book is that an attempt is made to connect the flora of a locality with the physical conditions which prevail there. It is a pity, however, that the author should have not adopted the names in common use for his plants-e.g. Scilla festalis the wild hyacinth or Volvulus for Convolvulus both look and sound pedantic. Moreover the glossary, which forms a necessary appendix, is sometimes disfigured by misleading statements; thus a carpel is stated to be that part of a flower which contains an ovary. But in spite of occasional slips and blemishes, the positive merits of the book should secure for it a fair measure of success.

The Journal of the Iron and Steel Institute. Name Index. Vols. I-L (1869-96). Edited by Bennett H. Brough. (London: E. and F. N. Spon, Ltd., I898.)

THE Iron and Steel Institute was founded in 1869, and since its establishment it has done most useful work by arranging periodical meetings for the discussion of practical and scientific subjects bearing upon the manufacture and use of iron and steel. The papers published in the Institute's Proceedings are here indexed, and they make a solid contribution to knowledge. The volume contains a short history of the Institute, a list of papers contained in the first fifty volumes arranged chronologically, a list of these papers arranged according to subjects, an index of the authors, and a complete index to the authors of all papers, communications, and abstracts published in the fifty volumes. The complete index will thus be of service in showing the development of the science of iron and steel.

A Simplified Euclid. Book I. By W. W. Cheriton. Preface by Elliott Kitchener. Pp. iv + I II. (London: Rivingtons, 1898.)

So many simplified Euclids have been published during the last few years, that an addition to their number should seem superfluous. In the one before ts the compiler claims that after teaching the subject for some years he thinks that the form he proposes in this book should supply a long-felt want. The method he adopts is to print the proposition exactly as it should be written out by a schoolboy, using sufficient abbreviations to save time in writing without confusing the mind of the pupil. Each proposition is printed on the left-hand side of the page, notes and exercises being printed on the right The book has many points in its favour. 